\title{
A new approach to the spectrophotometric determination of metronidazole and tinidazole using p-dimethylaminobenzaldehyde
}

\author{
OLAJIRE AREMU ADEGOKE* \\ OFFIONG EDET UMOH \\ Department of Pharmaceutical \\ Chemistry, Faculty of Pharmacy \\ University of Ibadan, Ibadan, Nigeria
}

\begin{abstract}
A new approach to the spectrophotometric determination of metronidazole (MZ) and tinidazole (TZ) has been developed. The procedure involves coupling of diazotized nitroimidazoles with $p$-dimethylaminobenzaldehyde (DMAB) to form a greenish-yellow solution. Optimal temperature and time were $0{ }^{\circ} \mathrm{C}$ (iced) and 3 minutes for diazotization and $30{ }^{\circ} \mathrm{C}$ and 2 minutes for coupling for both MZ and TZ. Coloured adducts of MZ and TZ showed shoulders at $406 \mathrm{~nm}$ and $404 \mathrm{~nm}$, respectively, which were selected as analytical wavelengths. The reaction with $p$-DMAB occurred in a 1:1 mole ratio. Beer's law was obeyed within the $4.8-76.8 \mu \mathrm{g} \mathrm{mL}^{-1}$ concentration range with low limits of detection. The azo adducts were stable for over a week. Molar absorptivities were $1.10 \times$ $10^{3}(\mathrm{MZ})$ and $1.30 \times 10^{3} \mathrm{~L} \mathrm{~mol}^{-1} \mathrm{~cm}^{-1}(\mathrm{TZ})$. Overall recoveries of $\mathrm{MZ}$ and $\mathrm{TZ}$ from quality control samples were $103.2 \pm 1.3$ and $101.9 \pm 1.3 \%$ over three days. There was no interference from commonly utilized tablet excipients. No significant difference was obtained between the results of the new method and the BP titrimetric procedures. The azo approach using the $p$-dimethylaminobenzaldehyde procedure described in this paper is simple, fast, accurate and precise. It is the first application of DMAB as a coupling component in the diazo coupling reaction.
\end{abstract}

Keywords: nitroimidazoles, diazotization, spectrophotometry, $p$-dimethylaminobenzaldehyde

Nitro derivatives of five-membered heterocyles are of considerable interest. Some are biologically active with anti-inflammatory or vasodilatory activity (1). The 5-nitroimidazoles are used as antiamoebic, antiprotozoal and antibacterial agents. Two important members of this chemical class are metronidazole and tinidazole. Discovery of the anti-trichomonal properties of metronidazole revolutionized the treatment of disease.

\footnotetext{
*Correspondence; e-mail: jireade@yahoo.com, ao.adegoke@mail.ui.edu.ng
} 
Chemically, metronidazole is 2-methyl-5-nitroimidazole-1-ethanol (MZ) and tinidazole is 1-(2-ethyl-sulphonyl ethyl)-2-methyl-5-nitroimidazole (TZ) (2). The biological activity of nitroimidazoles is dependent upon the nitro group reduction due to the formation of active intermediate species (3) that interact with DNA to produce biochemical damage. Reduction of the nitro group has been also used as a basis for determination of these drugs. Several methods have been reported for the determination of metronidazole and/or tinidazole in bulk and dosage forms or in biological fluids. Such methods include non-aqueous titration (4), voltammetric methods $(5,6)$, HPLC (7) and flow injection analysis (8). Some previously described spectrophotometric methods include the use of vanillin and anisaldehyde (9), p-benzoquinone (10), metol and $\mathrm{K}_{2} \mathrm{Cr}_{2} \mathrm{O}_{7}$ (11), alkaline hydrolysis (12), derivative spectrophotometry (13), extractive spectrophotometry using sodium 1,2-naphthaquinone-4-sulfonate after condensation reaction (14) and methylbenzothiazolin-2-one hydrazine (MBTH) (15) among others. These spectrophotometric methods have their relative merits but the majority of them are carried out at elevated temperatures, time consuming, use relatively expensive reagents, involve extraction, use of buffer systems, not all determine MZ and TZ and many are multi-step procedures. The ability of $p$-dimethylaminobenzaldehyde (DMAB) to form Schiff's bases with aromatic amines has been utilized for the spectrophotometric determination of compounds such as metronidazole (16) and hydralazine (17). In the varied applications of DMAB, none involved its use as a coupling component to diazonium ion. In this report, we present a simple, sensitive, cost-effective and accurate determination of nitroimidazoles using DMAB via azo dye formation.

\section{EXPERIMENTAL}

\section{Apparatus and reagents}

A UV/VIS spectrophotometer (Unicam Aurora, Pye Unicam, UK) was used. Metronidazole and tinidazole chemical reference substances were used (Sigma, USA). All reagents and solvents used were of analytical grade. The drugs selected for this study were obtained from pharmaceutical stores in Ibadan, Nigeria and are metronidazole brands: Loxagyl (May \& Baker Ltd., Nigeria), Metrodol (Pauco Pharm. Nigeria Ltd., Nigeria), Metrotabs (SKG Pharma Ltd., Nigeria), Tromet 500 infusion (Microlabs Ltd. India) while the tinidazole brand was Amtiba 500 (Cadila Pharm. Dholka, India).

Standard solutions of pure reference metronidazole and tinidazole $\left(1200 \mu \mathrm{g} \mathrm{mL}^{-1}\right.$, corresponding to $7 \times 10^{-3}$ and $4.9 \times 10^{-3} \mathrm{~mol} \mathrm{~L}^{-1}$, respectively) were prepared in methanol. A $0.1 \%\left(7.0 \times 10^{-3} \mathrm{~mol} \mathrm{~L}^{-1}\right) \mathrm{DMAB}$ solution was prepared in a solution of optimized sulphuric acid concentration of $0.5 \mathrm{~mol} \mathrm{~L}^{-1}$.

\section{Reduction of metronidazole and tinidazole}

The adopted general approach to determining the best reducing agent for nitroimidazoles involved reducing the $\mathrm{MZ}$ and $\mathrm{TZ}$ in 1,4-dioxan using the reduction systems: $\mathrm{Zn} / \mathrm{HCl}$ in ethanol at $90^{\circ} \mathrm{C}$, palladium-carbon/glacial acetic acid, $\mathrm{LiBH}_{4} /$ glacial acetic acid and $\mathrm{NaBH}_{4} /$ glacial acetic acid at room temperature. In each case, $0.25 \mathrm{~g}$ of the re- 
O. A. Adegoke and O. E. Umoh: A new approach to the spectrophotometric determination of metronidazole and tinidazole using p-dimethylaminobenzaldehyde, Acta Pharm. 59 (2009) 407-419.

ducing agent was incubated at appropriate temperature and the progress of reduction was assessed at 5-minute intervals. The optimum time required for the reduction process to go to completion was determined through the formation of salmon-pink colour with DMAB, indicating the conversion of the nitro group to amine.

\section{General procedure}

A 5-mL volume of $7 \times 10^{-3} \mathrm{~mol} \mathrm{~L}^{-1}$ solution of the reduced $\mathrm{MZ}$ or TZ solution (reduced with $\mathrm{LiBH}_{4}$ in methanol) was transferred to a $50-\mathrm{mL}$ calibrated beaker, $5 \mathrm{~mL}$ of 0.1 $\mathrm{mol} \mathrm{L}-1 \mathrm{NaNO}_{2}$ solution was added and the mixture was stirred for $2 \mathrm{~min}$. Then $5 \mathrm{~mL}$ of $0.2 \mathrm{~mol} \mathrm{~L}^{-1}$ sulfamic acid solution was added and stirred again for $1 \mathrm{~min}$, all at $0{ }^{\circ} \mathrm{C}$ (iced). Diazotized solutions were freshly prepared each day. Sample solutions for spot tests and TLC were prepared by mixing $1.0 \mathrm{~mL}$ of the DMAB solution and $1 \mathrm{~mL}$ of the diazotized drug. The colours obtained were recorded immediately and after $20 \mathrm{~min}$. Solutions of these azo adducts and that of DMAB were kept in a water bath $\left(80^{\circ} \mathrm{C}\right)$ and examined after $20 \mathrm{~min}$.

The analytical wavelength was selected by recording the spectra of DMAB, the reaction products with $\mathrm{MZ}$ and $\mathrm{TZ}$ as well as the spectra of diazotized MZ and TZ. The spectra were overlaid on each other and the analytical wavelength was selected by inspection.

Temperature and time optimization was done using the method of steepest ascent (18). This was carried out at 30,50,60 and $80^{\circ} \mathrm{C}$, after 5 and 20 minutes each. Eight test tubes each containing $0.5 \mathrm{~mL}$ of $0.12 \%\left(7 \times 10^{-3} \mathrm{~mol} \mathrm{~L}^{-1}\right)$ of reduced and diazotized metronidazole (MZ) was used. $p$-DMAB solution $(0.5 \mathrm{~mL} 0.1 \%)$ was added to each of the test tubes and vortexed. Methanol $(4 \mathrm{~mL})$ was added to each of the tubes to make up to 5 $\mathrm{mL}$ of reaction volume. At the end of the various reaction times and temperatures, the absorbance reading of each of the mixtures was taken at $406 \mathrm{~nm}$ with methanol as blank solvent. The same procedures were repeated for reduced and diazotized tinidazole (TZ) at $404 \mathrm{~nm}$. Optimization of the time required for coupling to take place at room temperature $\left(30{ }^{\circ} \mathrm{C}\right)$ was done at $0,2,5,10,20$ and 30 minutes. The reaction mixtures were made up to $5 \mathrm{~mL}$ at these times with methanol, and the absorbance readings were taken at 406 $\mathrm{nm}$ and $404 \mathrm{~nm}$ (MZ and TZ, respectively) with methanol as blank.

The analytical signal stability was assessed by measuring the absorbance of the adducts at the working wavelengths at 5-minute intervals for the first $30 \mathrm{~min}$, at 30-minute intervals for the next three hours and then daily for 7 days.

\section{Stoichiometric ratio determination}

Job's method of continuous variation (19) was used to determine the stoichiometric ratios at which the diazotized imidazoles combine with DMAB. Various volumes of diazotized solution of MZ/TZ were made up to $1.0 \mathrm{~mL}$ with the DMAB solution. The tubes were kept at $30{ }^{\circ} \mathrm{C}$ for $2 \mathrm{~min}$. At the end of the reaction time, methanol was added. The absorbance readings were taken at $406 \mathrm{~nm}$ for MZ and at $404 \mathrm{~nm}$ for diazotized TZ. Blank values were subtracted from that of the reaction mixture. All procedures were carried in duplicate. 


\section{Validation studies}

Calibration curves were prepared using concentrations of diazotized MZ and TZ of $0,4.8,9.6,19.2,38.4$ and $76.8\left(0,2.8,5.6,11.2,22.4,44.8 \times 10^{-5} \mathrm{~mol} \mathrm{~L}^{-1}\right.$ and $0,1.9,3.9,7.8$, $15.5,31.1 \times 10^{-5} \mathrm{~mol} \mathrm{~L}^{-1}$, respectively). $0.5 \mathrm{~mL}$ of $0.1 \%(\mathrm{~m} / \mathrm{V}) \mathrm{p}$-DMAB was added to each of the tubes. These were allowed to stand for 2 minutes after which respective volumes of methanol were added to make up to $5 \mathrm{~mL}$ of the reaction mixture. The absorbance readings of each mixture were recorded at 406 and $404 \mathrm{~nm}$, respectively.

The limit of detection $(D L)$ and limits of quantitation $(Q L)$ were calculated according to the current ICH guidelines (20) as 3.3 and 10 standard deviation of the blank $(n=$ 6) divided by the slope of the calibration curve. Model recoveries and repeatability of the new methods were carried out on three successive days as stipulated by the USP (21). Accuracy was estimated at three concentration levels and $95 \%$ confidence limits.

To study the potential interference from the commonly utilized tablet excipients and other additives such as starch, lactose, magnesium stearate, talc, gelatin and their mixtures, recovery studies of $38.4 \mu \mathrm{g} \mathrm{mL}^{-1}\left(0.224 \mathrm{mmol} \mathrm{L}^{-1}\right.$ and $0.155 \mathrm{mmol} \mathrm{L}^{-1}$, respectively) metronidazole and tinidazole from the matrices containing these excipients were carried out. Four replicates were analyzed for each drug.

\section{Assay of dosage forms}

Three different brands of metronidazole tablets, one brand of infusion and one brand of tinidazole tablets were analyzed. Mass uniformity test was carried out on the different brands, and the active ingredient assay was then carried out based on the new method for each brand.

An amount of powdered tablets equivalent to $0.03 \mathrm{~g}$ of metronidazole and tinidazole was reduced with $\mathrm{LiBH}_{4}$ and then diazotized. A 0.16-mL aliquot of each of the respective reduced and diazotized $\mathrm{MZ}$ and $\mathrm{TZ}$ stock solution (equivalent to $0.036 \mu \mathrm{mol}$ $\mathrm{MZ}$ and $0.025 \mu \mathrm{mol} \mathrm{TZ}$ ) was then transferred into test tubes. $0.5 \mathrm{~mL}$ of $0.1 \% p$-DMAB was added to each of the tubes. The reaction was allowed to proceed for $2 \mathrm{~min}$ after which methanol ( $4 \mathrm{~mL})$ was added. For MZ infusion, $6 \mathrm{~mL}$ of infusion solution was reduced and diazotized and $0.16 \mathrm{~mL}$ of the diazotized stock was used for coupling. The absorbance reading of the respective reaction mixtures was recorded at $406 \mathrm{~nm}$ and 404 $\mathrm{nm}$, respectively, for $\mathrm{MZ}$ and $\mathrm{TZ}$ using methanol as blank solvent. Official non-aqueous titration (4) was adopted for MZ and TZ tablets and the UV spectrophotometric method was used for the MZ infusion at $277 \mathrm{~nm}$. Six replicate determinations were carried out in each case.

\section{RESULTS AND DISCUSSION}

\section{Chemistry}

Metal hydrides were found to give the best results for the formation of the azo adduct between diazotized nitroimidazoles and DMAB among the reducing agents studied. A persistent yellowish-green colour was produced and was stable for seven days. This col- 
our is completely different from the salmon-pink produced after condensation reaction between reduced nitroimidazoles and DMAB (16). This is the first paper to report the use of $\mathrm{DMAB}$ as a coupling reagent in acidic solution. Since the dimethylamino moiety in DMAB has a moderate activating influence on the aromatic skeleton, ortho substitution of an incoming electrophile might be possible. This reaction will be further aided by the presence of the aldehyde group which is meta-directing. Thus the 3- and 5-positions on the DMAB molecule are equivalent and will be available for electrophilic attack. This was found true. This is illustrated in Scheme 1 showing the coupling of diazotized imidazoles with DMAB. Fig. 1 presents the structures of the new compounds produced between DMAB and MZ and TZ. The possibility of steric hindrance on substitution by diazotized nitroimidazoles is eliminated as the dimethylamino group is staggered from the diazo linkage (bond angle between N8, C14 and C12 for the TZ adduct is $120.456^{\circ}$ and that of the MZ adduct between N 18, C 10 and C 4 is $122.665^{\circ}$ ). This shows that the angles around a main chain nitrogen atom (the diazo linkage) are all approximately equal to 120 degrees: consequently, the group is planar. Likewise, the torsion angles are 0.94 and $0.339^{\circ}$, respectively, for the TZ-DMAB and MZ-DMAB adducts. Since the torsion is between 0 and $+90^{\circ}$, the stereochemical arrangement is of the syn type. Both molecules are therefore of the trigonal planar skeleton. Both the bond and torsion angles favour the formation of a stable adduct.

Thin layer chromatographic analyses using normal phase revealed the formation of new adducts distinct from both DMAB and diazotized nitroimidazoles. The result of the TLC analysis is presented in Table I. In both mobile phases adopted, the adducts were more non-polar than the starting materials. This is expected, since conjugation of the benzene ring with imidazoles should yield compounds with reduced polarity.

The overlaid absorption spectra of the drugs, DMAB and the new adducts are presented in Figs. 2a and b, respectively, for MZ and TZ. Coupling reaction of reduced and diazotized nitroimidazoles with $p$-DMAB gave an instant greenish-yellow colour, indi-

a)

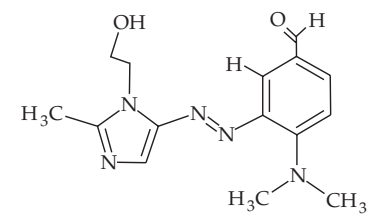

b)

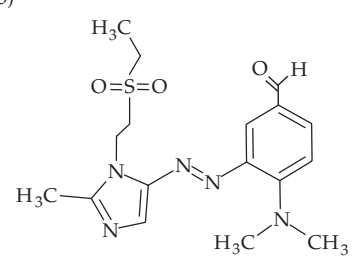

Fig. 1. Structures of the azo-adduct formed between DMAB and a) MZ and b) TZ.

Table I. $\mathrm{R}_{f}$ values of the thin layer chromatographic analysis

\begin{tabular}{lccc}
\hline \multicolumn{1}{c}{ Mobile phase } & MZ-DMAB & TZ-DMAB $^{\mathrm{a}}$ & DMAB $^{\circ}$ \\
\hline Ethyl acetate/methanol (9:1) & $0.90(0.76)$ & $0.91(0.79)$ & 0.83 \\
Chloroform/acetone (8:2) & $0.94(0.33)$ & $0.96(0.60)$ & 0.90 \\
\hline
\end{tabular}

${ }^{a} R_{\mathrm{f}}$ values for diazotized $\mathrm{MZ}$ and $\mathrm{TZ}$ in parentheses. 
cating the formation of azo adduct. The reduced and diazotized nitroimidazoles exhibited peaks at 210, 260, $360 \mathrm{~nm}(\mathrm{MZ})$ and 230, 300 and $350 \mathrm{~nm}$ (TZ). However, when reacted with $p$-DMAB, they formed azo dye of a characteristic greenish-yellow colour, as shown by the results of the spot tests. The peaks for MZ adduct were at 310, 350, $370 \mathrm{~nm}$ and a shoulder was at $406 \mathrm{~nm}$ while TZ adduct had a peak at $350 \mathrm{~nm}$ and a shoulder at $404 \mathrm{~nm}$. The analytical wavelength was selected as $406 \mathrm{~nm}$ and $404 \mathrm{~nm}$, respectively, representing the wavelength where optimal detector response was obtained between DMAB and the adduct with either MZ or TZ. Since diazotization is also a form of derivatization, it was more convenient to use the shoulders at 406 and $404 \mathrm{~nm}$, where diazotized nitroimidazoles have very low absorptivity, without compromising the accuracy. The slight difference in the absorption spectra of MZ and TZ can be attributed to the presence of different substituents on the molecules. Expectedly, the ethylsulfonylethyl fragment in the TZ molecule should have a slight deactivating influence on the new adduct compared to the ethanol moiety on MZ. However, the auxochromic effect is not very significant as only a $2 \mathrm{~nm}$ difference was observed in absorption at the shoulder.

\section{Optimization studies}

Optimization of reducing agents revealed the superiority of metal hydrides over the dissolving metals in glacial acid. The metal hydrides were used at room temperature as compared to the use of elevated temperatures typical of $\mathrm{Zn}$ and $\mathrm{Pd} / \mathrm{C}$ in ethanol or glacial acetic acid reported by previous methods of Ahmed and Onah (9), Rehamn et al. (10) and Siddappa et al. (16). Reduction was completed in 5 min using $\mathrm{LiBH}_{4}$. This is one of the advantages of this report, which provides convenience of analysis.

The optimum coupling temperature and time for the coupling of diazotized $\mathrm{MZ}$ and $\mathrm{TZ}$ with $p$-DMAB were established as $30{ }^{\circ} \mathrm{C}$ (room temperature) and 2 minutes. Higher
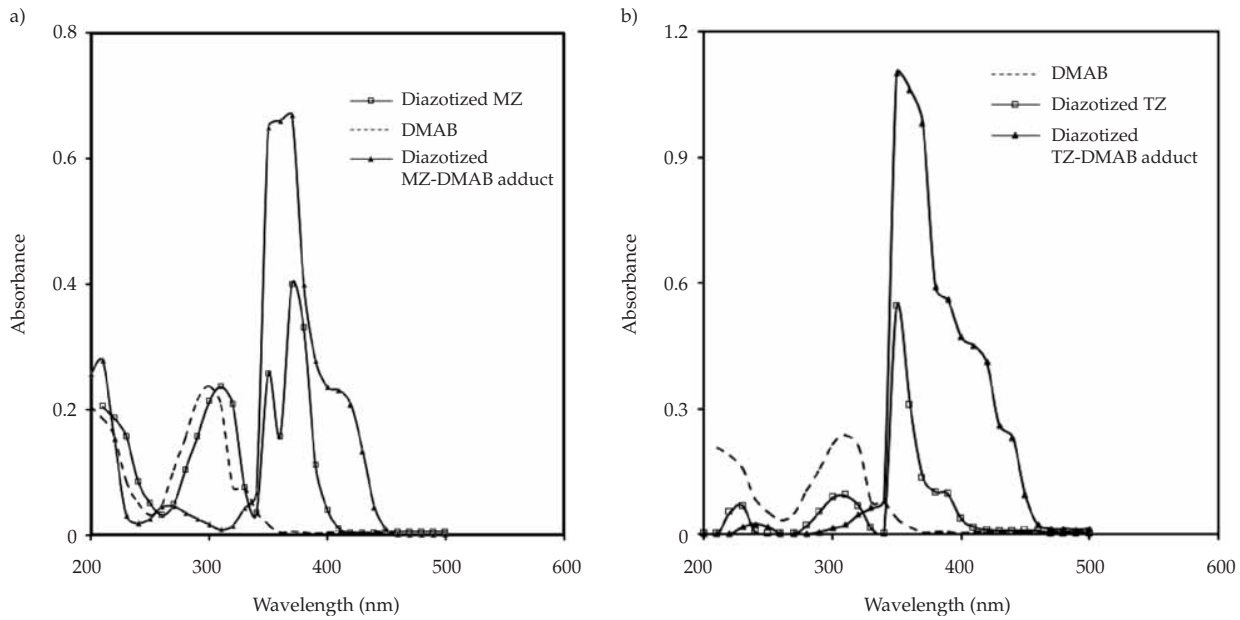

Fig. 2. Absorption spectra of: a) DMAB, diazotized MZ and the adduct formed and b) DMAB, diazotized TZ and the adduct formed. 
O. A. Adegoke and O. E. Umoh: A new approach to the spectrophotometric determination of metronidazole and tinidazole using p-dimethylaminobenzaldehyde, Acta Pharm. 59 (2009) 407-419.<smiles>Cc1ncc([N+](=O)[O-])n1CCO</smiles><smiles>[Y][13CH2][13CH3]</smiles><smiles>Cc1ncc(N)n1CCO</smiles>

Reduced MZ<smiles>[Y][C@H](C)O[N+](=O)[O-]</smiles><smiles>Cc1ncc([N+]#N)n1CCO</smiles>

Diazotized MZ<smiles>Cc1ncc(/N=N/c2cc(C=O)ccc2N(C)C)n1CCO</smiles>

(a) DMAB-MZ adduct<smiles>CCOS(=O)(=O)CCn1c([N+](=O)[O-])cnc1C</smiles>

TZ

Step I: Reduction

$\mathrm{H}^{+} \mathrm{LiBH}_{4}$<smiles>CCOS(=O)(=O)CCn1c(N)cnc1C</smiles>

Reduced TZ

Step II: Diazotization $\mathrm{NaNO}_{2} / \mathrm{H}^{+}$<smiles>CCOS(=O)(=O)CCn1c([N+]#N)cnc1C</smiles>

Diazotized TZ Coupling

Step III: Coupling reaction<smiles>CCOCCn1c(N=Nc2cc(C=O)ccc2N(C)C)cnc1C</smiles>

(b) DMAB-TZ adduct

Proposed names of azo adducts

(a) 4-(dimethylamino)-3-\{(E)-[1-(2-hydroxyethyl)-2-methyl-1H-imidazol-5-yl]diazenyl $\}$ benzaldehyde

(b) 4-(dimethylamino)-3-(\{1-[2-(ethylsulfonyl)ethyl]-2-methyl-1H-imidazol-5-yl $\}$ diazenyl)benzaldehyde

Scheme 1 
temperatures led to extremely low absorbance values. This implies that high temperatures destroy the azo adduct formed between the compounds.

The study of analytical signal stability for the two azo adducts at 404 and $406 \mathrm{~nm}$ revealed that absorbance was independent of time. The absorbance was constant over a period of seven days, when measured daily, with a loss of only about $7.4 \%$ for the MZ adduct and $6.5 \%$ for the $\mathrm{TZ}$ adduct.

The effect of water and methanol as diluting solvents was investigated after the coupling reaction. When methanol was used as solvent, higher absorbance readings, better regression equations, higher correlation coefficient and coefficient of determination were obtained compared to the values when water was used. This ability of methanol to cause high absorbance readings can be easily explained. The two processes leading to the coupling reaction, reduction and diazotization involve removal of water molecules; hence, any solvent that can sequester water molecules will favour the forward reaction, which will also bring about the formation of more complex molecules. Thus, methanol was chosen as the diluting solvent. It is also possible that the internal mesomeric effect within the carbonyl group on the DMAB molecule might be active in water and might cause some deactivation on the DMAB molecule. This reduces the possibility of coupling reaction taking place. However, the polar effect is eliminated in methanol and the strong activating influence of the dimethylamino fragment is optimal on thereby favouring the coupling reaction.

Optimal detector response was obtained when the diazotized nitroimidazoles combined at a mole ratio of 1:1 with DMAB as the coupling component. This corroborates the TLC result and hence the structure presented in Scheme 1 is justified.

\section{Validation}

The new approach produced excellent correlation for the regression of absorbance of the complex on the concentration of MZ $\left(R^{2}=0.9980\right)$ and TZ $\left(R^{2}=0.9983\right)$. Molar absorptivities were $1.1 \times 10^{3} \mathrm{~L} \mathrm{~mol}^{-1} \mathrm{~cm}^{-1}$ and $1.3 \times 10^{3} \mathrm{~L} \mathrm{~mol}^{-1} \mathrm{~cm}^{-1}$ and limits of detec-

Table II. Analytical and validation parameters for the assay of $M Z$ and $T Z$

\begin{tabular}{lcc}
\hline \multicolumn{1}{c}{ Parameter } & Metronidazole & Tinidazole \\
\hline Beer's law limits $\left(\mu \mathrm{g} \mathrm{mL}^{-1}\right)$ & $4.8-76.8$ & $4.8-76.8$ \\
Limit of detection $\left(\mu \mathrm{g} \mathrm{mL}^{-1}\right)$ & 1.41 & 1.94 \\
Limit of quantitation $\left(\mu \mathrm{g} \mathrm{mL}^{-1}\right)$ & 4.28 & 5.06 \\
Molar absorptivity $\left(\mathrm{L} \mathrm{mol}^{-1} \mathrm{~cm}^{-1}\right)$ & $1.1 \times 10^{3}$ & $1.3 \times 10^{3}$ \\
Regression equation & & \\
Intercept \pm CI & $0.0173 \pm 0.0046$ & $0.0125 \pm 0.0041$ \\
Slope \pm CI & $0.0048 \pm 0.00015$ & $0.0048 \pm 0.00013$ \\
Correlation coefficient, $R$ & 0.9990 & 0.9991 \\
\hline
\end{tabular}

a $Y=b X+a$, where $Y$ is the absorbance for concentration $X\left(\mu \mathrm{g} \mathrm{mL} L^{-1}\right)$

CI - confidence interval at $p \leq 0.05$. 
O. A. Adegoke and O. E. Umoh: A new approach to the spectrophotometric determination of metronidazole and tinidazole using p-dimethylaminobenzaldehyde, Acta Pharm. 59 (2009) 407-419.

Table III. Model recovery and repeatability of the new method

\begin{tabular}{|c|c|c|c|c|}
\hline \multirow{2}{*}{$\begin{array}{l}\text { Concentration } \\
\qquad\left(\mu \mathrm{g} \mathrm{mL}^{-1}\right)\end{array}$} & Day $1^{a}$ & Day $2^{a}$ & Day $3{ }^{\text {a }}$ & $\begin{array}{l}\text { Intermediate } \\
\text { precision }^{\mathrm{b}}\end{array}$ \\
\hline & Mean recovery $(\%)$ & Mean recovery $(\%)$ & Mean recovery $(\%)$ & RSD (\%) \\
\hline \multicolumn{5}{|c|}{ Metronidazole } \\
\hline 9.6 & $104.1 \pm 1.0$ & $104.1 \pm 1.0$ & $101.90 \pm 1.0$ & 1.1 \\
\hline 38.4 & $105.4 \pm 0.3$ & $104.8 \pm 0.3$ & $103.19 \pm 0.8$ & 0.6 \\
\hline 76.8 & $101.5 \pm 0.7$ & $102.5 \pm 1.0$ & $101.78 \pm 1.3$ & 1.1 \\
\hline \multicolumn{5}{|c|}{ Tinidazole } \\
\hline 9.6 & $101.0 \pm 1.1$ & $101.8 \pm 0.9$ & $101.47 \pm 1.8$ & 1.5 \\
\hline 38.4 & $105.0 \pm 0.7$ & $100.4 \pm 0.6$ & $102.27 \pm 2.0$ & 1.2 \\
\hline 76.8 & $102.6 \pm 0.8$ & $101.0 \pm 0.4$ & $100.94 \pm 1.6$ & 0.9 \\
\hline
\end{tabular}

a $n=12$

${ }^{\mathrm{b}} n=9$

tion of 1.41 and $1.94 \mu \mathrm{g} \mathrm{mL}^{-1}$ and $Q L s$ of 4.28 and $5.06 \mu \mathrm{g} \mathrm{mL}^{-1}$ were obtained, respectively, for MZ and TZ. The various validation parameters and optical properties for the new procedures are presented in Table II. The overall model recoveries for MZ and TZ adducts were in the order of $103.2 \pm 1.3 \%$ and $101.9 \pm 1.3 \%$. The model recovery and repeatability of the new methods for the assay of $\mathrm{MZ}$ and $\mathrm{TZ}$ are presented in Table III. Table IV contains the intra-day assessment of the accuracy and precision of the new method for the assay of nitroimidazoles. The mean recovery of the new method when compared to the official method is presented in Table IV. The recovery for MZ ranged from 98.0-99.5 and for TZ it was $100.3 \%$, showing the suitability of the new method for the analysis of metronidazole and tinidazole in dosage forms. One of the most promising features of this new approach to the spectrophotometric determination of $\mathrm{MZ}$ and $\mathrm{TZ}$ is the absence of interference from commonly utilized excipients in tablet formulations. The

Table IV. Intra-day model accuracy and precision of the new method

\begin{tabular}{cccc}
\hline Drug & Added $\left(\mu \mathrm{g} \mathrm{mL}^{-1}\right)$ & Found $^{\mathrm{a}} \pm \mathrm{CI}\left(\mu \mathrm{g} \mathrm{mL}^{-1}\right)^{\mathrm{a}, \mathrm{b}}$ & RSD $(\%)$ \\
\hline \multirow{2}{*}{$\mathrm{MZ}$} & 9.6 & $9.9 \pm 0.1$ & 1.0 \\
& 38.4 & $40.1 \pm 0.3$ & 0.9 \\
& 76.8 & $78.3 \pm 0.3$ & 0.4 \\
$\mathrm{TZ}$ & 9.6 & $9.8 \pm 0.01$ & 0.1 \\
& 38.4 & $38.9 \pm 0.3$ & 1.0 \\
\hline
\end{tabular}

a Mean \pm SD for 6 determinations.

$\mathrm{b}$ Confidence limits for the concentrations found at $p=0.05$ and 5 degrees of freedom. 
O. A. Adegoke and O. E. Umoh: A new approach to the spectrophotometric determination of metronidazole and tinidazole using p-dimethylaminobenzaldehyde, Acta Pharm. 59 (2009) 407-419.

Table V. Interference studies of commonly used excipients

\begin{tabular}{ccccccc}
\hline & \multicolumn{6}{c}{ Recovery $(\%)^{\mathrm{b}}$} \\
\cline { 2 - 6 } Drug $^{\mathrm{a}}$ & Lactose & Talc & $\begin{array}{c}\text { Magnesium } \\
\text { stearate }\end{array}$ & Gelatin & Starch & $\begin{array}{c}\text { Mixture of } \\
\text { the excipients }\end{array}$ \\
\cline { 2 - 7 } MZ & $103.6 \pm 0.6$ & $103.7 \pm 0.4$ & $103.3 \pm 0.2$ & $104.4 \pm 1.4$ & $103.3 \pm 0.2$ & $104.4 \pm 0.6$ \\
TZ & $100.5 \pm 0.2$ & $101.1 \pm 0.2$ & $100.8 \pm 0.2$ & $100.68 \pm 0.3$ & $100.4 \pm 0.1$ & $100.8 \pm 0.2$ \\
\hline
\end{tabular}

a Concentration of each drug: $38.4 \mu \mathrm{g} \mathrm{mL} \mathrm{m}^{-1}$.

${ }^{\mathrm{b}}$ Mean $\pm \mathrm{SD}, n=4$.

recoveries obtained for $\mathrm{MZ}$ and $\mathrm{TZ}$, respectively, in the presence of excipients are in the order of 100.5-104.4\%. The results are presented in Table V. This lack of interference from tablet excipients is another advantage of this new method.

\section{Application of the new method}

The applicability of the new method described in this report for the assay of metronidazole infusion and tablets as well as tinidazole in tablets was examined and the results obtained were statistically compared with the official methods using F-ratio test, $t$-test, confidence limits and ANOVA. The results are presented in Table VI. The recovery of metronidazole and tinidazole from the dosage forms obtained by new method ranged

Table VI. Determination of metronidazole and tinidazole in pharmaceutical preparations

\begin{tabular}{|c|c|c|c|c|c|c|c|c|}
\hline \multirow[b]{2}{*}{$\begin{array}{c}\text { Drug } \\
\text { formulation }\end{array}$} & \multicolumn{2}{|c|}{ New method ${ }^{a}$} & \multicolumn{2}{|c|}{ Official method (4) } & \multirow[b]{2}{*}{$\begin{array}{c}\text { Mean recovery } \\
\pm \mathrm{SD}(\%)\end{array}$} & \multirow[b]{2}{*}{$\begin{array}{c}\text { Error } \\
(\%)\end{array}$} & \multicolumn{2}{|c|}{ Statistics $^{b}$} \\
\hline & $\begin{array}{l}\text { Concentra- } \\
\text { tion found } \\
\left(\mu \mathrm{g} \mathrm{mL} L^{-1}\right)\end{array}$ & $\begin{array}{l}\text { RSD } \\
(\%)\end{array}$ & $\begin{array}{c}\text { Concentration } \\
\text { found } \\
\left(\mu \mathrm{g} \mathrm{mL}^{-1}\right)\end{array}$ & $\begin{array}{l}\text { RSD } \\
(\%)\end{array}$ & & & $F$-value & $t$-value \\
\hline \multicolumn{9}{|c|}{ Metronidazole } \\
\hline $\begin{array}{l}\text { Metrodol } \\
\text { tablet }\end{array}$ & 39.4 & 0.5 & 39.6 & 0.9 & $99.5 \pm 0.6$ & 0.5 & 1.13 & 1.06 \\
\hline $\begin{array}{l}\text { Loxagyl } \\
\text { tablet }\end{array}$ & 39.4 & 0.7 & 39.9 & 1.0 & $98.7 \pm 0.6$ & 1.3 & 4.36 & 2.09 \\
\hline $\begin{array}{l}\text { Metrotab } \\
\text { tablet }\end{array}$ & 39.3 & 1.2 & 40.1 & 1.1 & $98.0 \pm 0.5$ & 2.0 & 2.70 & 1.64 \\
\hline $\begin{array}{l}\text { Tromet-500 } \\
\text { infusion }\end{array}$ & 39.2 & 0.9 & 39.9 & 1.0 & $98.2 \pm 0.9$ & 1.8 & 1.52 & 1.23 \\
\hline \multicolumn{9}{|c|}{ Tinidazole } \\
\hline $\begin{array}{l}\text { Amtiba-500 } \\
\text { tablet }\end{array}$ & 39.5 & 0.8 & 39.4 & 0.7 & $100.3 \pm 0.8$ & 0.3 & 0.02 & 0.15 \\
\hline
\end{tabular}

a Mean value, $n=6$. Content of metronidazole tablet and that of infusion stipulated by BP $=95-105 \%$.

b Statistical analyses done between the results obtained from the proposed method and the BP official non-aqueous titration (theoretical $t$-value $=2.776$, theoretical $F$-value $=6.39$ ). 
between 98.0 and $100.3 \%$ when compared with the official non-aqueons titrimetric procedure. Presented data suggest the ability of the new method to analyze metronidazole and tinidazole in the tablet and infusion matrices with good accuracies and precision comparable to that of official method.

\section{CONCLUSIONS}

The new approach of utilizing $p$-dimethylaminobenzaldehyde as a coupling component is the first of such reports. The method adopted for the determination of nitroimidazoles (metronidazole and tinidazole) is simple, accurate, sensitive, and less time-consuming and free from extreme experimental conditions such as heating at high temperatures. It was successfully adopted for the analysis of these drugs in dosage forms. Some obvious advantages of this new approach to the determination of nitro-imidazoles include simplicity, accuracy, low cost and speed. Even though the method is a two-step approach, it compared favourably with other previously reported methods.

\section{REFERENCES}

1. A. R. Katritzky, E. F. V. Scriven, S. Majumder, R. G. Akhmedova, N. G. Akhmedov and A. V. Vakulenko, Direct nitration of five membered heterocycles, ARKIVOC iii (2005) 179-191.

2. A. Gennaro, Remington's Pharmaceutical Sciences, 18th ed., Mack Publishing Co., Easton 1993, pp. $1228-1230$.

3. R. J. Knox, R. C. Knight and D. I. Edwards, Interaction of nitroimidazole drugs with DNA in vitro: structure-activity relationships, Br. J. Cancer 44 (1981) 741-745.

4. British Pharmacopoeia, Her Majesty's Stationery Office, London 2001.

5. A. Z. A. Zuhri, S. I. Al-Khalil and M. S. Suleiman, Electrochemical reduction of metronidazole and its determination in pharmaceutical dosage forms by DC polarography, Anal. Lett. 19 (1986) 453-459.

6. G. O. El-Sayed, Polarographic determination of metronidazole in pharmaceutical formulations and urine, Microchem. J. 55 (1997) 110-114; DOI:10.1006/mchj.1996.1307.

7. K. B. Mustapha, M. T. Odunola, M. Garba and O. Obodozie, Rapid, cost-effective liquid chromatograghic method for the determination of metronidazole in biological fluids, Afr. J. Biotech. 5 (2006) 1188-1190.

8. S. S. Simoes, P. M. Everado, N. G. Everado, S. L. Wellington, N. T. M. Pablo, C. U. A. Mario, C. S. Edvan and B. N. Valberes, Flow injection determination of metronidazole through spectrophotometric measurement of the nitrite ion produced upon alkaline hydrolysis, J. Braz. Chem. Soc. 17 (2006) 609-613; DOI: 10.1590/S0103-50532006000300028.

9. B. H. Ahmed and J. O. Onah, Colorimetric determination of chloramphenicol and metronidazole in pharmaceutical formulations after Schiff-base formation with vanillin and anisaldehyde, Global J. Pure Appl. Sci. 9 (2003) 359-364.

10. A. Rehman, A. S. Ijaz and A. Raz Spectrophotometric determination of metronidazole in pharmaceutical dosage forms using p-benzoquinone, J. Iran. Chem. Soc. 2 (2005) 197-202. 
O. A. Adegoke and O. E. Umoh: A new approach to the spectrophotometric determination of metronidazole and tinidazole using p-dimethylaminobenzaldehyde, Acta Pharm. 59 (2009) 407-419.

11. C. S. P. Sastry, M. Aruna and A. R. M. Rao, Spectrophotometric determination of some antiamoebic and anthelmintic drugs with metol and chromium (VI), Talanta 35 (1988) 23-26; DOI: 10.1016/0039-9140(88)80006-7.

12. L. Lopez Martine, F. J. Luna Hernandez and P. L. Lopez Alba, Simple spectrophotometric determination of tinidazole in formulation and serum, Anal. Chim. Acta 340 (1997) 241-244; DOI: 10.1016/ S0003-2670(96)00508-9.

13. C. V. Prasad, V. Sripriya, R. N. Saha and P. Parimoo, Simultaneous determination of tinidazole, furazolidone and diloxanide furoate in a combined tablet preparation by second-derivative spectrophotometry, J. Pharm. Biomed. Anal. 21 (1999) 961-968; DOI: 10.1016/S0731-7085(99)00190-9.

14. N. D. Dinesh, P. Nagaraja and K. S. Rangappa, A sensitive spectrophotometric assay for tinidazole and metronidazole using a Pd-C and formic acid reduction system, Turk. J. Chem. 28 (2004) 335-344

15. P. Nagaraja, K. R. Sunitha, R. A. Vasantha and H. S. Yathirajan, Spectrophotometric determination of metronidazole and tinidazole in pharmaceutical preparations, J. Pharm. Biomed. Anal. 28 (2002) 527-53; DOI: 10.1016/S0731-7085(01)00685-9.

16. K. Siddappa, M. Mallikarjun, P. T. Reddy and M. Tambe, Spectrophotometric determination of metroniodazole through Schiff's base system using vanillin and PDAB reagents in pharmaceutical preparations, Ecle. Quím. (Sao Paulo) 33 (2008) 41-46; DOI: 10.1590/S0100-46702008000400005.

17. O. A. Adegoke and C. E. Nwoke, Spectrophotometric determination of hydralazine using $p$-dimethylaminobenzaldehyde, J. Iran. Chem. Soc. 5 (2008) 316-323.

18. H. T. Karnes and C. March, Precision, accuracy and data acceptance criteria in biopharmaceutical analysis, Pharm. Res. 10 (1993) 1420-1426.

19. J. Rose, Advanced Physico-Chemical Experiments, Pitman, London 1964, p. 54.

20. ICH Topic Q2 (R1), Validation of Analytical Procedures: Text and Methodology (CPMP/ICH/281/ 95); accessed June 30, 2008.

21. United States Pharmacopoeia 24/National Formulary 19, US Pharmacopoeial Convention, Rockville 2000, p. 819.

$S A \check{Z} E T A K$

\section{Novi pristup spektrofotometrijskom određivanju metronidazola i tinidazola koristeći $p$-dimetilaminobenzaldehid}

OLAJIRE AREMU ADEGOKE i OFFIONG EDET UMOH

U radu je opisan novi način spektrofotometrijskog određivanja metronidazola (MZ) i tinidazola (TZ). Postupak uključuje reakciju diazotiranog nitroimidazola s $p$-dimetilaminobenzaldehidom (DMAB), pri čemu nastaje zelenkasto-žuta otopina. Optimalna temperatura i vrijeme za diazotaciju su $0{ }^{\circ} \mathrm{C}$ (ledena kupelj) i 3 minute, a za reakciju kondenzacije $30{ }^{\circ} \mathrm{C}$ i 2 minute. Obojeni adukti imaju maksimum apsorpcije pri 406, odnosno $404 \mathrm{~nm}$ pa su te valne duljine izabrane za analitički postupak. Reakcija s p-DMAB zbiva se u množinskom omjeru 1:1. Reakcija slijedi Beerov zakon u koncentracijskom rasponu $4,8-76,8 \mu \mathrm{g} \mathrm{mL}^{-1} \mathrm{~s}$ niskim granicama detekcije. Azo adukti su stabilni preko tjedan dana. Molarna apsorptivnost bila je 1,10 × $10^{3}(\mathrm{MZ})$, odnosno $1,30 \times 10^{3} \mathrm{~L} \mathrm{~mol}^{-1} \mathrm{~cm}^{-1}$ (TZ). Ukupni povrat MZ i TZ iz kontrolnih uzoraka bio je 103,2 $\pm 1,3$, odnosno 101,9 $\pm 1,3 \%$ tijekom tri dana. Nije zamijećena nikakva interferencija uobičajenih pomoćnih tvari koje 
O. A. Adegoke and O. E. Umoh: A new approach to the spectrophotometric determination of metronidazole and tinidazole using p-dimethylaminobenzaldehyde, Acta Pharm. 59 (2009) 407-419.

se koriste za tabletiranje. Ne postoji značajna razlika između rezultata dobivenih novom metodom i rezultata dobivenih BP titrimetrijskim postupkom. Metoda određivanja opisana u ovom radu je jednostavna, brza, pogodna, točna i precizna i po prvi puta uključuje DMAB u reakciji diazo kopulacije.

Ključne riječi: nitroimidazoli, diazotacija, spektrofotometrija, p-dimetilaminobenzaldehid

Department of Pharmaceutical Chemistry, Faculty of Pharmacy, University of Ibadan, Ibadan, Nigeria 